\title{
Bilateral hearing loss as an initial presentation of Creutzfeldt-Jakob disease
}

\author{
Janaina Mariana de Araujo Miranda Brito-Marques ${ }^{1}{ }^{\oplus}$, Eduardo Sousa de Melo ${ }^{1,2}{ }^{\bullet}$, \\ Fabíola Lys de Medeiros ${ }^{1 \odot}$, Cristiano Sobral de Carvalho ${ }^{1 \odot}$, Paulo Roberto de Brito-Marques ${ }^{1,3 \odot}$
}

\begin{abstract}
We reported a case of a 61-year-old male patient with anacusis, cerebellar syndrome, myoclonus, and frontal signs. The brain magnetic resonance imaging showed bilateral striated hyperintensity of the fluid-attenuated inversion recovery and restricted diffusion in the diffusion-weighted imaging and hypointense areas corresponding to the apparent diffusion coefficient in the cerebral cortex. The autopsy revealed positive immunohistochemistry for the PrPSc protein. Creutzfeldt-Jakob disease presenting with hearing loss is unusual.
\end{abstract}

Keywords: dementia, prion disease, hypoacusis.

\section{PERDA AUDITIVA BILATERAL COMO UMA APRESENTAÇÃO INICIAL DA DOENÇA DE CREUTZFELDT-JAKOB}

RESUMO. Relatamos o caso de um paciente do sexo masculino, 61 anos, com anacusia, síndrome cerebelar, mioclonia e sinais frontais. A ressonância magnética cerebral mostrou hiperintensidade estriada bilateral do fluid-attenuated inversion recovery (FLAIR) e difusão restrita no diffusion-weighted imaging (DWI) e áreas hipointensas correspondendo ao coeficiente de difusão aparente no córtex cerebral. A autópsia revelou imuno-histoquímica positiva para a proteína PrPSc. A doença de CreutzfeldtJakob que se apresenta com perda auditiva é incomum.

Palavras-chave: demência, doença de príon, hypoacusis.

\begin{abstract}
$\mathrm{A}^{\mathrm{a}}$ 61-year-old man presented with progressive bilateral hearing loss, and gait disturbance for 2 months. On examination, he presented anacusis, cerebellar syndrome, myoclonus, and frontal signs. Brain magnetic resonance imaging (MRI) showed bilateral striatum fluid-attenuated inversion recovery hyperintensity and restricted diffusion on diffusion-weighted imaging and corresponding apparent diffusion coefficient hypointense areas in the cerebral cortex (Figure 1). The electroencephalogram (Figure 2) showed three-phase periodic activity (0.8$1.3 \mathrm{~Hz}$ ). Cerebrospinal fluid was in range, tau protein was $440 \mathrm{ng} / \mathrm{L}$ (slightly elevated), and 14-3-3 protein was negative. Auditory
\end{abstract}

evoked potential revealed severe bilateral dysfunction of the vestibulocochlear nerves. In addition, laboratory tests, anti-thyroid peroxidase (TPO) test, autoimmune tests, and paraneoplastic screening were performed with negative results. The patient developed progressive cognitive worsening, akinetic mutism, and cortical blindness. After 5 weeks in hospital, the patient developed aspiration pneumonia progressing to sepsis and death. The pathology with immunohistochemistry was positive for PrPSc protein.

In the literature, few cases of bilateral hearing loss have been reported as an initial symptom of Creutzfeldt-Jakob disease (CJD). In our review, these cases were

\footnotetext{
This study was conducted by the Hospital Universitário Oswaldo Cruz de Universidade de Pernambuco, Recife, PE, Brazil.

'Department of Neurology, Hospital Universitário Oswaldo Cruz, Universidade de Pernambuco - Recife, PE, Brazil. Department of Neuropsychiatry, Unit of Neurology and Neurosurgery, Universidade Federal de Pernambuco - Recife, PE, Brazil. ${ }^{3}$ Medical Sciences College, University of Pernambuco, Recife, PE, Brazil.

Janaina Mariana de Araujo Miranda Brito-Marques. Department of Neurology, Hospital Universitário Oswaldo Cruz, Universidade de Pernambuco. Rua Arnóbio Marques, 310 - Santo Amaro - 50100-130 Recife PE - Brazil. E-mail: marianaaraujo6@gmail.com

Disclosure: The authors report no conflicts of interest.

Funding: none.

Received on June 26, 2021. Accepted in final form on September 20, 2021.
}

\section{(cc) BY}




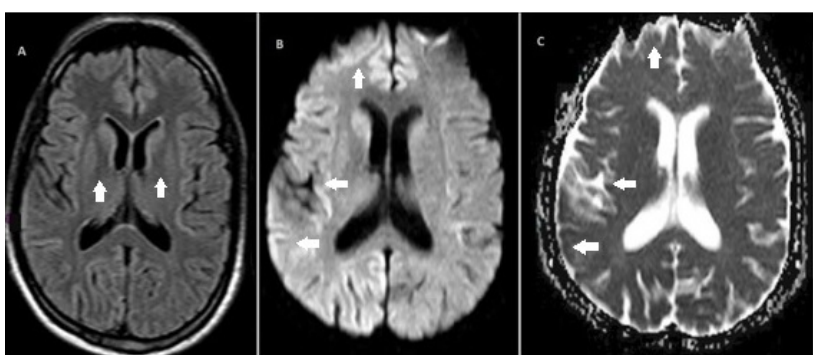

Figure 1. Brain MRI. Panel A show hyperintensity in bilateral striatum in the FLAIR sequence. Panels $B$ and $C$ shows water restriction in cortex with a predominance in the right hemisphere (DWi/ADC map).

evaluated with audiometry and/or auditory evoked potentials. In only one of the cases, the auditory evoked potentials showed a central pattern of hearing loss. Two cases, including ours, had vestibulocochlear pattern involvement, another case was normal, and in the remaining cases, it was not possible to carry out the test or if the result was inconclusive. ${ }^{1-6}$

Other causes of hearing loss associated with progressive encephalopathy should be taken under consideration, such as Whipple's disease, Lyme disease, human immunodeficiency virus, Susac disease, sarcoidosis, central nervous system vasculitis, lymphoma, and paraneoplastic disease. ${ }^{4}$

Prion disease should be considered in cases of rapidly progressive dementia with myoclonus; however, in one-third of the cases, it may initially manifest with atypical symptoms such as aphasia, pure ataxia, and visual or hearing loss. In atypical cases, the recognition of typical patterns for CJD on the brain is MRI and is of great importance to guide for further investigation. $[5,6]$ Despite of bilateral hearing loss being a rare form of initial presentation of CJD, it should be part of the differential diagnosis of progressive encephalopathies with auditory symptoms.
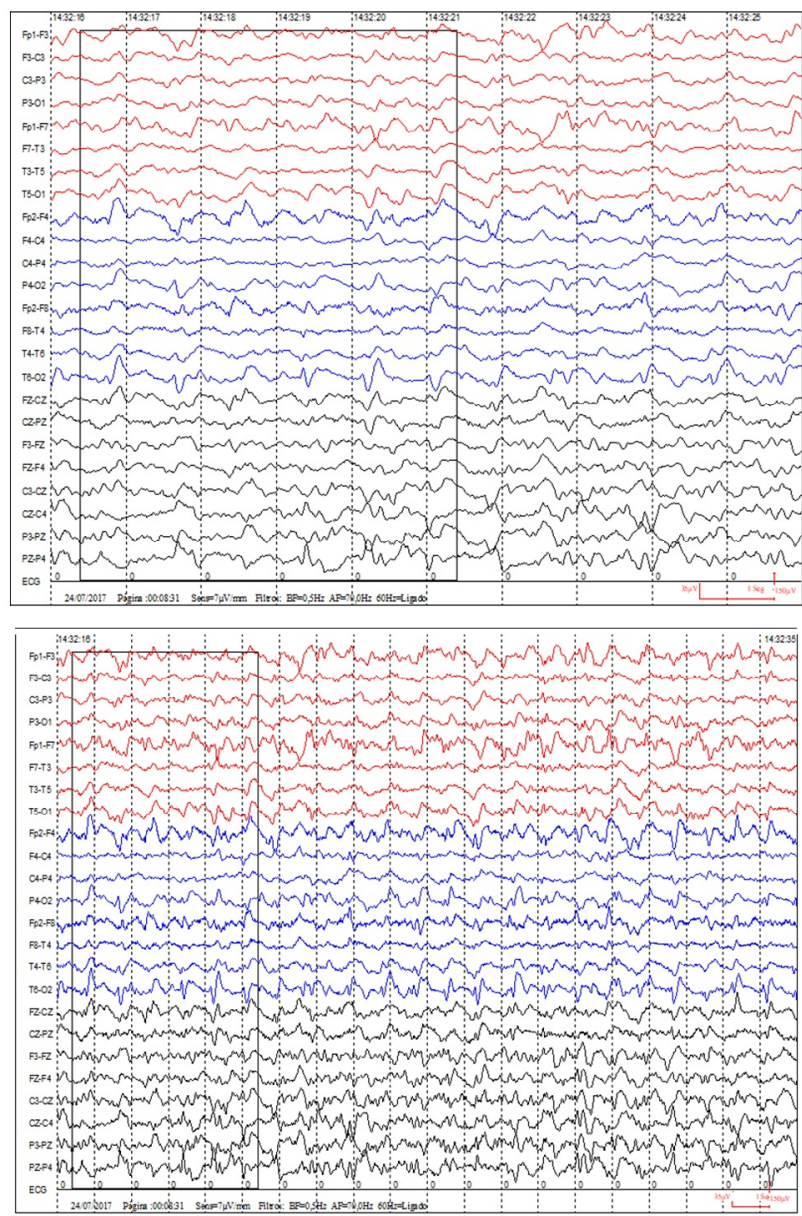

Figure 2. Electroencephalogram with periodic activity, biphasic or triphasic morphology, of $0.8-1.3$ seconds, with diffuse distribution, lateralized to the right cerebral hemisphere, and predominantly posterior.

Authors' contributions. JMAMBM: manuscript writing, study concept, and design. ESM, FLM, CSC, and PRBM: study concept and design.

\section{REFERENCES}

1. Krishna P, Bauer C. Hearing loss as the initial presentation of Creutzfeldt-Jakob disease. Ear Nose Throat J. 2004;83(8):535, 538, 540 passim. PMID: 15487633

2. Reñé R, Campdelacreu J, Ferrer I, Escrig A, Povedano M, Gascón-Bayarri J, et al. Familial Creutzfeldt-Jakob disease with E200K mutation presenting with neurosensorial hypoacusis. BMJ Case Rep. 2009;2009:bcr06.2009.2006. https://doi.org/0.1136/bcr.06.2009.2006

3. Bigelow DC, Eisen MD, Yen DM, Saull SC, Solomon D, Schmidt DE. Otolaryngological manifestations of Creutzfeldt-Jakob disease. Arch Otolaryngol Head Neck Surg. 1998;124(6):707-10. https://doi.org/10.1001/ archotol.124.6.707

4. Prodi E, Rossi S, Bertaina I, Pravatà E, Sacco L. Report of a case of Creutzfeldt-Jakob disease with an unusual clinical presentation. Front Behav Neurosci. 2020;14:55. https://doi.org/10.3389/fnbeh.2020.00055

5. Salazar R, Cerghet M, Ramachandran V. Bilateral hearing loss heralding sporadic Creutzfeldt-Jakob disease: a case report and literature review. Otol Neurotol. 2014;35(8):1327-9. https://doi.org/10.1097/ MAO.0000000000000485

6. Geschwind MD, Murray K. Differential diagnosis with other rapid progressive dementias in human prion diseases. Handb Clin Neurol. 2018;153:371397. https://doi.org/10.1016/B978-0-444-63945-5.00020-9 